NBER WORKING PAPER SERIES

\title{
HISTORICAL POLITICAL FUTURES MARKETS: AN INTERNATIONAL PERSPECTIVE
}

\author{
Paul W. Rhode \\ Koleman Strumpf \\ Working Paper 14377 \\ http://www.nber.org/papers/w14377
NATIONAL BUREAU OF ECONOMIC RESEARCH
1050 Massachusetts Avenue
Cambridge, MA 02138
October 2008

We thank Gianni Toniolo, Erik Snowberg, Alan Taylor, and Justin Wolfers for insights and suggestions. The views expressed herein are those of the author(s) and do not necessarily reflect the views of the National Bureau of Economic Research.

NBER working papers are circulated for discussion and comment purposes. They have not been peerreviewed or been subject to the review by the NBER Board of Directors that accompanies official NBER publications.

(C) 2008 by Paul W. Rhode and Koleman Strumpf. All rights reserved. Short sections of text, not to exceed two paragraphs, may be quoted without explicit permission provided that full credit, including (C) notice, is given to the source. 
Historical Political Futures Markets: An International Perspective

Paul W. Rhode and Koleman Strumpf

NBER Working Paper No. 14377

October 2008

JEL No. G10,N12,N14,P16

\section{ABSTRACT}

Political future markets, in which investors bet on election outcomes, are often thought a recent invention. Such markets in fact have a long history in many Western countries. This paper traces the operation of political futures markets back to 16th Century Italy, 18th Century Britain, and 19th Century United States. In the United States, election betting was a common part of political campaigns in the antebellum period, but became increasingly concentrated in the organized futures markets in New York City over the postbellum period.

Paul W. Rhode

Economics Department

Eller College of Management

University of Arizona

Tucson, AZ 85721-0108

and NBER

pwrhode@email.arizona.edu

Koleman Strumpf

University of Kansas

cigar@ku.edu 
Election betting markets have been growing in popularity. These markets are chiefly an internet phenomenon, leveraging the ability of a large number of participants to quickly and cheaply place wagers on the outcome of upcoming elections. The first such market, the Iowa Political Stock Market, was founded in 1988 and involved modest stakes and only a few hundred traders. The more recent incarnations, most prominently Intrade and Betfair, have thousands of traders and involve millions of dollars in wagers. There is strong evidence that prices in these markets provide accurate forecasts of election outcomes. ${ }^{1}$

The prominence of internet election markets often obscures the long history of such exchanges. Betting on elections has been going on for hundreds of years in many western countries. The absence of these markets in the mid-20th century is more the exception than the rule.

In this paper we document the history of election markets. These markets reflect the prevailing culture and electoral institutions. Betting focused on the most important political outcomes of the time: papal selection in $16^{\text {th }}$ century Italy, the timing and winning party of Parliamentary elections in $18^{\text {th }}$ and $19^{\text {th }}$ century Britain, and Presidential and Congressional winners in the $19^{\text {th }}$ century United States. There were also markets on other political events, such as the outcome of no-confidence votes, the tenure of leaders and their successors, or the outcome of foreign/military ventures. ${ }^{2}$

We focus on the historical evolution of the legality and microstructure of political betting markets commonly referred to as prediction markets. The first two sections describe the earliest markets in Italy as well as Great Britain and its former colonies. The third section turns to the United States. During the antebellum period informal bets were common in virtually every city, indeed they was a core part of most campaigns, yet there did not exist a centralized, formalized betting market generating odds prices reflecting changing expectations about election outcomes. Following the Civil War, more explicit

\footnotetext{
${ }^{1}$ Justin Wolfers and Eric Zitzewitz (2004). "Prediction Markets." Journal of Economic Perspectives. 18. 107-126. Paul W. Rhode and Koleman Strumpf (2004). "Historical Presidential Betting Markets." Journal of Economic Perspectives. 18. 127-142. Paul W. Rhode and Koleman Strumpf (2008). "Manipulating Political Stock Markets: A Field Experiment and a Century of Observational Data." working paper available at http://people.ku.edu/ cigar.

${ }^{2}$ There were also markets which indirectly captured election outcomes. Insurance premia, exchange rates, and security prices of politically-connected assets often reflect (or span) the same fundamentals that would drive political stock market prices.
} 
markets emerged and betting activity became concentrated in New York City. Due in part to changes in the legality of election betting, the New York markets moved from poolrooms to the Curb Market and uptown hotels and finally to illegal bucket shops on Wall Street. ${ }^{3}$ The markets largely disappeared or went underground at about the time of the Second World War as scientific polling came into its own. ${ }^{4}$

\section{The First Markets: Italian City States and the Vatican}

Election betting was common in the Italian city-states in the early modern period, 1500-1700. ${ }^{5}$ In addition to voting, selection to public office often included intentional randomization, for example, drawing lots to name the nominators or candidates. In Venice and Genoa, gambling on the outcome of local elections was popular. Bellhouse suggests that the Genoese lottery, one of the first modern numbers games, originated with betting on the drawing of lots - pulling balls associated with specific candidates from an urn. ${ }^{6}$ Political betting continued into Italy's recent history including, at times, as part of its national lotto (established in 1863). For example, in the pivotal 1948 election, the state-run lottery experimented with a "totalvoto" pool allowing betting on the composition of parliament. ${ }^{7}$ Figure 1 displays a 1948 "Totalvoto" ticket for sale recently at EBay Italy.

Gamblers have also long wagered on the selection to offices in the Catholic Church. Quotes of betting odds on papal succession appear as early as 1503 when such wagering was already considered "an old practice." 8 During the troubled papal conclave of 1549, the Venetian ambassador Matteo Dandolo observed that the Roman "merchants

\footnotetext{
${ }^{3}$ Bucket shops operated off-site from the official exchange and catered to low-stakes investors who bet on whether stock prices would rise or fall.

${ }^{4}$ For a more formal analysis of the post-bellum U.S. markets, see Paul W. Rhode and Koleman Strumpf (2004). "Historical Presidential Betting Markets." Journal of Economic Perspectives. 18. 127-142.

5 Jonathan Walker, "Gambling and the Venetian Noblemen, c. 1500-1700," Past and Present, no. 162, (Feb. 1999), pp. 28-69, esp. p. 31 on the practices of scommetter, betting on elections.

${ }^{6}$ D. R. Bellhouse, "The Genoese Lottery," Statistical Science, 6:2 (May 1991), pp. 141-48; Nicole Martinelli, "Online Gaming, Italian Style," Wired, 18 December 2006.

${ }^{7}$ The New York Times, 30 March 1948, p. 12; Washington Post, 30 March 1948, p. 7, 1 April 1948, p. 1; and 25 April 1948, p. M5; Scotsman, 17 April 1948, p. 5. The left-wing parties were initially favored in the betting, but their odds fell by election day. During the campaign, the Communists protested against the inclusion of the electoral contest within the national lottery system. But the winner of the 60 million lire prize was a supporter of the Communist Popular Front.

${ }^{8}$ Frederic J. Baumgartner, Behind Locked Doors: A History of Papal Elections. (New York: Palgrave, 2003), pp. 88, 250.
} 
are very well informed about the state of the poll, and ... the cardinals' attendants in Conclave go partners with them in wagers, which thus causes many tens of thousands of crowns to change hands." 9 Odds were offered not only on which candidate among the papabile would win but also on when the conclave would end. About two months into this long and conflict-filled process, the market odds were 10 to 1 (implying a probability of approximately 9 percent) that this conclave would never elect a pope. Aversion to such activities eventually led Pope Gregory XIV, in March 1591 to ban on pain of excommunication all betting on the outcome of papal elections, the length of the papal reign, or the creation of cardinals.

Gregory XIV's threat pushed wagering over papal succession underground, but at times it resurfaced. As a 1878 New York Times article noted: "The deaths and advents of the Popes has always given rise to an excessive amount of gambling in the lottery, and today the people of Italy are in a state of excitement that is indescribable. Figures are picked out which have some relation with the life or death of Pius IX. Every day large sums are paid for tickets in the lottery about to be drawn."10 Betting over the successor to Leo XIII in 1903 and to Benedict XV in 1922 attracted considerable press attention. ${ }^{11}$ With the recent rise of internet betting markets, betting on the new pope could again occur in public on a large scale.

\section{Election Betting in the Anglo-American World}

\section{A. Britain}

Political betting also has a long history in Great Britain. As an example, Charles James Fox, the late $18^{\text {th }}$-century Whig statesman, was known as an inveterate gambler. His biographer, George Otto Trevelyan noted that "(f)or ten years, from 1771 onwards, Charles Fox betted frequently, largely, and judiciously, on the social and political

\footnotetext{
${ }^{9}$ Frederic J. Baumgartner, "Henry II and the Papal Conclave of 1549," Sixteenth Century Journal, Vol. 16, No. 3 (Autumn 1985), pp. 301-314, quote on p. 305.

${ }^{10}$ New York Times, 2 March 1878, p. 2.

${ }^{11}$ New York Times, 11 July 1903, p. 2; Atlanta Constitution, 11 July 1903, p. 3; Chicago Tribune, 27 July 1903, p. 4; Los Angeles Times, 18 August, 1903, p. 5; Scotsman, 24 January 1922, p. 4 and 7 February $1922,5$.
} 
occurrences of the time." 12 His wagers recorded in the betting book of the Brooks' Club included whether the Tea Act would be repealed, how long Lord North's minister would last, or on other events related to the coming of the American Revolution. Such activity at gentleman's clubs (such as Almack's, Brooks', White's, Boodle's) as well as in less elite public coffeehouses was considered in keeping with national tradition: "As far back as the reign of William the Third, foreigners had observed that, on matters great and small, the only sure test of English opinions was the state of the odds." "13 A common phrase was "Bet or be silent."14

Wagering was generally legal under British common law, so long as it did not to lead to immortality or impolity. ${ }^{15}$ Bets about the outcome of events in war, over the death of political leaders, over court cases, or between voters over election results were illegal on these grounds. ${ }^{16}$ In the Victorian and Edwardian periods, the British government increasingly attempted to limit gambling, especially among the working classes. The Gaming Act of 1845 made gambling contracts and debts unenforceable in court (but otherwise liberalized what amounts could be wagered); the Betting Houses Act of 1853 outlawed the operation of betting establishments other than private clubs; the Betting Houses Act of 1874 cracked down of the advertisement of wagering; and the Street Betting Act of 1906 made acceptance of wagers in streets and public places illegal. ${ }^{17}$ Still in the late $19^{\text {th }}$ and early $20^{\text {th }}$ century, the Fleet Street press occasionally

\footnotetext{
${ }^{12}$ George Otto Trevelyan, The Early History of Charles James Fox (1880), p. 416 and New York Times, 7 November 1880 , p. 4.

${ }^{13}$ Trevelyan, Fox, p. 414. For an account of partisan betting behavior in the 1837 parliamentary contest, see Charles Greville and Henry Reeve, The Greville Memoirs: A Journal of the Reigns of King George IV. and King William IV, Vol. II (New York, Appleton, 1883), p. 510.

${ }^{14}$ John Robert Robinson, The Last Earls of Barrymore, 1769-1824 (London: S. Low-Marston, 1894) pp. $113-14$.

${ }^{15}$ Among the court cases decided on gaming were Foster v. Thackery (1781) regarding the outbreak of war between England and France; Allen v. Maur (1786) 1 Term Reports 56, regarding an election wager between two voters; Atherfold v. Beard (1788) 2 Term Reports 610, regarding the level of the duty on hops; Lacaussade v. White (1798) 7 Term. Reports 535, regarding the date when England and France would sign articles of peace. British Parliament, House of Lords, The Three Reports from the Select Committee on the Lords Appointed to Inquire into the Laws Respecting Gaming, (London, 1844) pp. 41-42. For the legal standing of wagers, see T. Starkie, "Appendix I: Substance of the Common and Statute Law Relating to Gaming,? pp. 223-31 in House of Commons, Report from the Select Committee on Gaming; Together with the Minutes of Evidence, Appendix and Index, (London, 1844).

${ }^{16}$ Joseph Chitty, A Treatise on the Laws of Commerce and Manufactures and the Contracts Related Thereto: With an Appendix of Precedents, Vol. III (London: A. Strahan, 1824), pp. 82-83.

${ }^{17}$ David Dixon, From Prohibition to Regulation: Bookmaking, Anti-Gambling, and the Law (Oxford: Clarendon Press, 1991), pp. 38-81; Mark Clapson, A Bit of a Flutter: Popular Gambling and English
} 
reported on election wagering at the London Stock Exchange and at Lloyd's in markets for Parliamentary "majorities."18

The Economist noted that during the interwar years: "there was a considerable amount of gambling on the composition of the next parliament. At one time there were extensive dealings in 'majorities' on the Stock Exchange."'19 The quoted prices for the shares of party seats in the 1924 contest were somewhat off but those in the 1929 contest were closer to the mark. Real problems arose in the 1931 race when the market significantly under-estimated the number of seats that the National government would win. $^{20}$ "There was a much publicized lawsuit when a trader, unable to honour his debts, pleaded the provisions of the Gaming Act. The sequel was a ban by the Council of the Stock Exchange on all such dealings, which has been reaffirmed at each subsequent election." ${ }^{21}$ For the 1935 election, betting moved from the Exchange to London bookmakers. This did not totally end such betting in the City. In the autumn of 1940, during the battle for Britain, London brokers among others ran organized betting sweepstakes regarding how many German planes would be shot down each night. The winnings were used to fund the construction of Spitfire fighters. ${ }^{22}$

In the immediate post-WWII period, public election betting in Britain appears to have slowed to a trickle. Newspapers offer only a handful of quotes regarding the 1945 and 1950 contests. And in 1950, the Economist observed: "It is curious that in a nation devoted to gambling as the British, so little opportunity should nowadays be taken of a general election, the most sporting of all events." ${ }^{, 2}$ This situation changed with time.

The modern era of open, large-scale political betting in Britain began in October 1963. Following Harold Macmillan’s surprise resignation as Prime Minister after the Profumo Affair, the gambling house Ladbroke's overcame the "long-standing reluctance

Society (Manchester: Manchester Univ. Press, 1992), pp. 18-38;Jim Orford, Kerry Sproston, Bob Erens, Clarissa White, and Laura Mitchell, Gambling and Problem Gambling in Britain (Hove, Britain, BrunnerRoutledge, 2003), p. 3

18 "Latest Parliamentary Betting," Punch, 21 July 1894. (which may be meant ironically); Times of London, 5 December 1910, p. 6, and 7 December 1910, p. 12 (which are not). Annual Register: A Review of Public Events at Home and Abroad for the Year 1910 (London, Longsmans-Green, 1911), pp. 256-57.

19 "Election Gambling," Economist, 4 February 1950, p. 252. See also Toronto Star, 13 October 1924, p. 1; Scotsman, 14 December 1928, p. 8.

${ }^{20}$ New York Times, 27 October 1931, p. 1.

21 "Election Gambling," Economist, 4 February 1950, p. 252.

22 Toronto Star, 26 October 1940.

${ }^{23}$ Election Gambling," Economist, 4 February 1950, p. 252. 
to make book on political events" by taking bets on his successor as leader of the Conservative party. ${ }^{24}$ Prior to 1963 , Ladbroke's had handled the political betting demands of its more gentlemanly clientele in a private election book. ${ }^{25}$ In 1964, William Hill, the country's largest bookmaker, also "quickly reversed its earlier policy not to handle election betting." ${ }^{26}$ By the end of that year, political betting totaled an estimated $£ 1,000,000$ (the equivalent of over \$25 million in today’s money.) About nine-tenths of this sum was placed on British contests, including the Wilson-Heath general election, and about one-tenth placed on the 1964 American presidential race. Political markets represented less than 2 percent of national gambling turnover. Several features of the political markets' microstructure were notable: the stakes were anonymously wagered; house profit rates averaged about 7 percent (taking in $£ 107$ for every £100 it pays out); and professional bookmakers set the fixed lines rather than accept bets in the form of pools. This last feature mattered at times when, for example, Mr. Hill set a line too favorable to a candidate he supported. ${ }^{27}$ In 1965, the London bookmakers began offering odds on the German election contests. And in early 1966, with new general elections in Britain, they handled over $£ 2,100,000$. This was purportedly the largest total ever taken on a single event. ${ }^{28}$ Despite complaints about the immorality of such wagering, the British betting public never looked back. ${ }^{29}$

\footnotetext{
24 “Odds-On Politics," Economist, 21 August 1965, pp. 715-16.

${ }^{25}$ New York Times, 10 May 1964.

26 "Whirl in the Pools," Economist, 17 October 1964, p. 273. Entire article is pp. 273-75.

27 “Odds-On Politics," Economist, 21 August 1965, pp. 715-16.

${ }^{28}$ Martin Rosenbaum, "Betting and the 1997 British General Election," Politics (1999) 19:1, pp. 9-14,

29 "Election Betting Scored in Britain; Wager Affect Voters and Results, Opponents Say," New York Times, 5 April 1966, p. 5.
} 


\section{B. British Commonwealth Countries}

Similar bouts of political betting occurred in many of the British offshoots with parliamentary forms of government throughout the late $19^{\text {th }}$ and early $20^{\text {th }}$ centuries. In countries including Canada, South Africa, and the Republic of Ireland, local bookmakers and members of the Stock Exchanges periodically wagered over the outcome of no confidence votes, the timing of the elections, and the composition of the new majority. ${ }^{30}$

In Canada, there were many reports of betting over results in both national and local elections during the late $19^{\text {th }}$ century. For example, the Toronto World had several reports on betting markets covering the 1882 and 1887 Parliamentary elections, the 1886 West Quebec Provincial election, and the 1885 and 1887 Toronto mayoral elections. ${ }^{31}$ There was additional coverage of gambling on many of the Parliamentary elections through 1930, with a half a million dollars bet in 1911 alone. In addition, there were occasionally active markets on local elections. ${ }^{32}$ While many of the bets were one-shot affairs involving prominent individuals, there were more traditional markets associated with the stock exchanges in Toronto and Montreal. ${ }^{33}$ The Toronto Star provided extensive coverage of election betting in the United States, reporting New York City odds right before election day to bring its readers up to date. ${ }^{34}$

\footnotetext{
${ }^{30}$ For examples of election betting in Ireland, see the discussion of the Dail Eireann (lower house of the Irish Parliament) in Scotsman, 5 January 1933, p. 9; for South Africa, see Scotsman, 13 June 1929, p. 9. Interestingly there is little evidence of early betting markets in Australia, perhaps stemming from laws which allowed bookmakers to accept wagers on horse racing but no other events (the latter restrictions were lifted in the 1980s).

${ }^{31}$ The issues of the Toronto World are: 8 June 1882 for the 1882 Parliamentary election; 22 and 25 February 1887 for the 1887 Parliamentary elections; 1 October 1886 for the West Quebec election; 6 January 1885 for the 1885 Toronto mayoral election; 3, 4, and 5 January 1887 for the 1887 Toronto mayoral election. ${ }^{32}$ Canadian Parliamentary elections are discussed in Manitoba Daily Free Press, 5 March 1891; New York Times, 30 October 1904, and Toronto Star, 1 November 1904; New York Times, 22 September 1911; Scotsman, 28 July 1930. There were also markets on a by-election in London Ontario, see Toronto World, 20 November 1920, as well as a market on Quebec provincial election, see Winnipeg Free Press, 19 October 1939.

${ }^{33}$ The Montreal markets are discussed in New York Times, 22 September 1911.

${ }^{34}$ As examples, see Toronto Star, 2 November 1896, 2 November 1908, 5 November 1912, 4 November 1916, 4 November 1924.
} 


\section{Election betting in the United States}

In this section we trace the development of American betting markets in the $19^{\text {th }}$ through $20^{\text {th }}$ centuries. A more formal analysis of the forecasting accuracy and financial efficiency of these markets is described in two companion papers. ${ }^{35}$

\section{A. Pre-Civil War}

Betting on political events was commonplace in the United States ever since the early national period. ${ }^{36}$ Advocates of a candidate frequently offered public bets on his behalf as a standard part of the election campaign. This became expected sign of support, even for races of lesser offices. As an example, William Cooper of Cooperstown, New York enjoyed the strong betting backing of his friends during his race for Congress in 1796. ${ }^{37}$ Political wagering became especially intense during the partisan conflicts of the Jacksonian era. ${ }^{38}$ The practice fit into the spirit of campaigning in this period with its torch-lit parades, chanting partisans, hard cider, and captive newspapers. In this era, most press outlets were closely tied to the political machines of either the Democrats or the Whigs. Newspapers were at the heart of much of the early betting activity. ${ }^{39}$ Many of the

\footnotetext{
${ }^{35}$ Paul W. Rhode and Koleman Strumpf (2004), "Historical Presidential Betting Markets." Journal of Economic Perspectives. 18. 127-142 and Paul W. Rhode and Koleman Strumpf (2004). "Historical Prediction Markets: Wagering On Presidential Elections.” working paper available at http://people.ku.edu/ cigar. $\frac{}{36}$ As early examples, see Connecticut Gazette, 17 December 1800, p. 2; and the Democrat, 10 November 1804, p. 2.

${ }^{37}$ Alan Taylor, "'The Art of Hook \& Snivey': Political Culture in Upstate New York during the 1790s," Journal of American History (March 1993), p. 1386, entire piece is pp. 1371-96. Taylor considered "bets between the friends of candidates" one of four main instruments in early electioneering (p. 1380). He notes "rival interests strove to intimidate one another and to impress voters with bets. A bet between the supported of rival interests was an exercise in competitive self-assertion. A public bet on a candidate was an investment of reputation and honor as well as of money."

${ }^{38}$ As examples at the beginning of this era, see Baltimore Patriot, 9 November 1824, p. 2; and NewHampshire Patriot \& State Gazette 1, December 1828, p. 2. Glenn C. Altschuler and Stuart M. Blumin, Rude Republic: Americans and their Politics in the Nineteenth Century (Princeton, NJ: Princeton University Press, 2000), p. 73 hold that while political parties were not directly responsible for most election betting in the period, they did encourage the practice among their partisans.

Several noteworthy recent surveys of political history in the early national and Jacksonian period, including Sean Wilentz, The Rise of American Democracy: Jefferson to Lincoln (New York: W.W. Norton, 2005) and Michael F. Holt, The Rise and Fall of the American Whig Party: Jacksonian Politics and the Onset of the Civil War (New York: Oxford Univ. Press, 1999) are remarkably silent about election betting. ${ }^{39}$ Regarding the political scene in New York in the 1790s, Taylor, "The Art of Hook \& Snivey," p. 1386 writes "the newspaper office became a kind of brokerage house for wagers. There a gentleman could leave a note or bond indicating what he would bet on a candidate; there a rival gentleman could agree to take up that note or bond or leave one of their own. The curious could call to inquire about who had bet and how
} 
election betting articles that appeared in the press were boasts or challenges rather than reports of actual wagers transacted. As one instance, "to test the sincerity" of local supporters of Gen. Jackson who "express their entire confidence in the success of their favorite candidate," John Leach issued a slate of a dozen bets in his local newspaper during the 1828 contest. ${ }^{40}$ The Albany Argus, voice of the New York regency, published its own list of challenges in 1832 and $1836 .{ }^{41}$ Similar advertisements to wager appear during most other major elections of the period. ${ }^{42}$

We know that it was not all bluster; real money was wagered. For example, archival records show that in late October 1832, John Nevitt of Natchez, Mississippi placed a $\$ 960$ bet on Andrew Jackson's re-election. This sum was worth the equivalent of $\$ 20,000$ today and was more than double what Nevitt annually paid the manager of his Clermont plantation. ${ }^{43}$

Such big-money wagering was not limited to private citizens. Politicians were often involved. As candidate for the Governor of New York in 1828, Martin Van Buren wrote to a follow politico: "Bet on Kentucky, Indiana and Illinois jointly if you can, or any two of them; don't forget to bet all you can., ${ }^{, 4}$ Battles between the Jackson forces and the "Bankites" raged during the 1832 contest. ${ }^{45}$ And in 1834, Van Buren's son, John, and friend, Jesse Hoyt, record making over one hundred election bets, amounting to $\$ 12,000$ to $\$ 15,000$ (\$290-360,000 in today's money). At this time, John Van Buren was New York Attorney General and Martin Van Buren was the nation's Vice President. ${ }^{46}$ As another indication of the involvement of elected officials, the Washington DC correspondent for the North American reported in early 1840: "Some heavy bets were

\footnotetext{
the wagers stood. Like the accumulation of nomination notices in the papers, reports of the ebb and flow of bets served as public opinion polls"

${ }^{40}$ New-Hampshire Statesman and Concord Register. 20 September 1828.

${ }^{41}$ Essex Gazette, 25 October 1828, p. 2; New-Hampshire Patriot \&State Gazette, 10 September 1832; and Connecticut Courant, 29 August 1836

${ }^{42}$ As examples, see the Spirits of the Times, 8 September and 20 October 1832; the Globe (Washington, DC), 6 October 1836, Barre Gazette, 30 October 1840, p. 2.

${ }^{43}$ John Nevitt Diary, Manuscripts Department, UNC-CH, Southern Historical Collection, MSS \# 543, 27 October and 12 December. 1832

${ }^{44}$ Edward M. Shepard, American Statesman: Martin Van Buren (Boston: Houghton-Mifflin, 1900), pp 453.

${ }^{45}$ Augustus C. Buell, History of Andrew Jackson: Pioneer, Patriot, Soldier, Politician, President. Vol . II, (New York: Charles Scribner, 1904), pp. 270-72.

${ }^{46}$ William L. MacKenzie, The Life and Times of Martin Van Buren (Boston: Cooke, 1846), pp. 255-56; New-Hampshire Patriot and State Gazette, 10 September 1832, p. 3; Vermont Gazette, 6 October 1832, p 2; Eastern Argus Semi-Weekly, 22 October 1832, p.2, and the Pittsfield Sun, 25 October 1832, p. 3.
} 
made between members of the House, to-day, on the approaching Presidential Election. ${ }^{, 47}$ Election betting in 1840 was carried on as never before. ${ }^{48}$ The 1844 contest between Henry Clay and James Polk witnessed an even greater flurry of betting. ${ }^{49}$ Press reports indicate more than $\$ 6$ million ( $\$ 138$ million in current dollars) changed hands in New York in the 1844 contest between Clay and Polk. ${ }^{50}$

\section{B. The Ebb and Flow of Election Betting}

To provide a better sense of the ebb and flow of election betting in the antebellum period, we surveyed the historical newspapers and periodicals available in the leading online sources - African American newspapers of the $19^{\text {th }}$ century; the Cengage-Gale $19^{\text {th }}$ Century US Newspapers, PaperofRecord.com, the Proquest American Periodical Survey and Historical Newspapers, and the Readex Early American Newspapers -- for relevant articles over the 1800 to 1860 period. Our tabulation excludes articles concerning legislative action to outlaw election betting as well as those discussing non-financial bets. This survey found roughly 150 articles. The cumulative distribution of this sample is displayed in Figure 2. The sample contains a small number of articles in the first decade of the $19^{\text {th }}$ century, but observations drop off during the so-called "Era of Good Feelings" (1815-1823) period. The number of articles picks up in the mid-1820s with the beginning of the Jacksonian movement and Whig reaction. The peak of activity occurs in 1840 and 1844, and then falls off again. Activity falls in 1850s before rising during 1860 election season. ${ }^{51}$

Wagering on elections became highly controversial. In 1840, Van Buren supporters charged British gold was being invested in "bragging bets" and "buying votes"

\footnotetext{
${ }^{47}$ North American and Daily Advertiser, (Philadelphia) 26 February 1840.

${ }^{48}$ The Farmers' Cabinet, 13 November 1840, p. 2

${ }^{49}$ New York Herald, 15 September 1844, Daily National Intelligencer, (Washington, DC), 5 September 1844; Boston Daily Atlas, 25 September 1844; Scioto Gazette, (Chillicothe, OH), 31 October 1844.

${ }^{50}$ New-Hampshire Patriot (Concord, NH), 5 December 1844, p [4].

${ }^{51}$ The number of newspapers covered in the online sources generally expand over time, This makes interpreting these trends somewhat problematic. The decline in the number of observations on election betting articles after 1844 is even more significant once the expansion in overall coverage is taken into consideration.
} 
in favor of Harrison. ${ }^{52}$ In turn, in the aftermath of the 1844 contest, the Whigs protested that a combination of gamblers favoring Polk had committed voting fraud using the winnings from election bets to defray their expenses. ${ }^{53}$ New York Governor Silas Wright complained vigorously in his 1845 message to the state legislature of "the extensive and rapidly increasing practice of betting upon elections, and the interested and selfish, and corrupting tendencies which it exerts upon the election itself." Wright urged the legislature to make election betting a criminal offense. ${ }^{54}$ The evangelical reform movements associated the "Second Great Awakening" also preached long and hard against election betting. ${ }^{55}$ And the Illinois Supreme Court did invalidate one bet as "against public policy and the best interests of the whole country." "56 Election betting was commonly considered a form of vote buying. ${ }^{57}$

With the collapse of the Second Party system and the ongoing Democratic-Whig rivalry, election betting appears to have slowed. ${ }^{58}$ We can only speculate why. By the late 1840 s, a large number of states had made election betting illegal. The re-orientation of the parties and the development of intense sectional conflicts may have reduced the

\footnotetext{
${ }^{52}$ See New-Hampshire Patriot, 7 September 1840, for these specific charges and 14 September 1840 for a more general criticism of corrupting influences of election betting from the Democratic side. See Pittsfield Sun, 22 October 1840, p. 2 for the slate of bets allegedly offered by agents of the "British Whigs."

${ }^{53}$ David Bacon, "The Mystery of Iniquity: A Passage in the Secret History of American Politics, Illustrated by a View of Metropolitan Society," Part II, American Whig Review, July 1845; Calvin Colton, The Life and Times of Henry Clay, Vol. II (New York: A.S. Barnes, 1846) p. 443. The alleged frauds against Clay echoed in Republican charges against the Tilden campaign in 1876. See Republican Campaign Textbook for 1880 (Washington, DC: Republican Congressional Committee, 1880), p. 57.

${ }_{54}$ MacKenzie, Life and Times, p. 205. Such messages were often mixed. In December 1838, Pennsylvania Governor Joseph Ritner (Anti-Masonic party) had railed against the vogue for election betting, "the very worst and most pernicious species of gambling... a people is preparing for despotism when it turns the elective franchise of its highest offices into a mere subject of pecuniary speculation." Atkinson's Saturday Evening Post, 5 January 1839, p. 2. But earlier in the election season, the pro-Ritner Philadelphia newspaper, the Pennsylvania Inquirer and Daily Courier, 20 August 1838, offered to bet $\$ 10,000$ in his favor in the race for governor against David Porter. (For a counter-offer, see Harrisburg Reporter and State Journal, 21 September 1838). In this hotly-contested election which ended in the so-called "Buckshot War," the sum wagered purportedly totaled over one-half million dollars. Colored American, 28 November 1838.

${ }^{55}$ New York Evangelist, 6 July 1839, p. 106; Christian Register and Boston Observer, 12 December 1840, p. 200; Christian Reflector, 8 August 1844, p. 125; Christian Inquirer, 27 November 1858, p. 2

${ }^{56}$ The case involved a wager on the 1864 presidential contest. Cleveland Morning Herald, 8 August 1871.

${ }^{57}$ Altschuler and Blumin, Rude Republic pp. 71-72; North American and Daily Advertiser, (Philadelphia), 23 June 1840. In criticizing the "ridiculous, immoral, and pernicious custom" of betting on elections, the Middlesex Gazette, 8 October 1828, p. 2 noted the practice was "quite prevalent in many States, but it is unfashionable in New England," adding "long may it remain so,"

${ }^{58}$ For examples of election betting in the 1850 s, see Mississippian and State Gazette, (Jackson), 25 June 1852; Vermont Watchman and State Journal (Montpelier), 21 October 1852; the Pittsfield Sun, 24 July 1856, and Bangor Daily Whig and Courier, 10 November 1856.
} 
sphere of personal contact leading to wagering as well as trust that the losing stake would actually be paid. Political wagering did not disappear as the career of Abraham Lincoln makes clear. In 1857, his firm handled a case involving a bet over the 1856 presidential election. $^{59}$

Much of the activity in the period surrounding the Civil War took the form of public challenges, for propaganda purposes. In 1864, August Belmont, a wealthy New York Democrat and representative of the Rothschild's interests in America, boasted he would "bet heavily on McClellan's election." His terms, however, represented a conditional wager, stating that McClellan's victory would bring peace but Lincoln's reelection would result in continued war and eventual disunion. ${ }^{60}$ Other proposals were offered for bragging rights and were not serious wagers. An extreme example of this purportedly occurred in 1868 when New York drug store owner, H. T. Helmbold, offered to bet $\$ 1$ million cash at even odds to take the Democratic side on a slate of election propositions. J. Kinsey Taylor of Philadelphia offered to take Grant's side. ${ }^{61}$ It is unclear whether both sides actually staked this wager. Such even-money boasts do not provide a meaningful set of odds concerning which candidate would win the election. But markets generating such odds would soon come.

\section{Post-Civil War}

Election betting involving real financial stakes occurred in almost every city. But increasingly over the postbellum period, such wagering became organized in markets centralized in New York City. In the late 1860s and early 1870s, activity was focused in pool halls such as Johnson's and Morrissey's. Betting in this period took the recentlydeveloped pari-mutuel form. That is, participants would buy fixed-dollar shares in the final pot and the odds would be determined at the end of all betting (a candidate's final odds of winning was determined by the proportion the total bet volume which was wagered on him). The New York dailies report substantial activity in the national and state contests of the 1870 s, but the form of betting make the odds difficult to translate

\footnotetext{
${ }^{59}$ Jesse W. Weik, The Real Lincoln: A Portrait (Boston, Houghton-Mifflin, 1923), pp. 174-176.

${ }^{60}$ New York Times, 26 October 1864, p. 4, 31 October 1864, p. 43 November 1864, p. 4, 5 November 1864, p. 4, 7 November 1864, p. 4.

${ }^{61}$ Charleston Courier, Tri-Weekly, 31 October 1868; North American and United States Gazette (Philadelphia), 30 October 1868.
} 
into subjective probabilities. In addition, problems arose with the 1876 Hayes-Tilden contest. This election was essentially a draw with the political parties charging each other with fraudulently manufacturing votes. The House of Representative eventually decided this highly contested election. The acrimony spilled over into the betting market, where $\$ 4$ million was wagered. ${ }^{62}$ John Morrissey, the leading New York pool-seller and an active Democrat, opted to cancel the pools, returning the stakes minus his commission. This solution left many unsatisfied, contributing to the push in the next session of the New York legislature to outlaw pool-selling.

After a brief lull in the late 1870 s and early 1880 s, election betting revived in the mid-1880s and began to flourish in the 1890s. Activity moved out of pool rooms onto the Curb Exchange in the financial district and to the major Broadway hotels. The politically-connected hotels included the Republican-oriented Fifth Avenue Hotel and the neighboring Democratic/Tammany-oriented Hoffman House. ${ }^{63}$ The Metropol and Waldorf Astoria were also locations for betting on elections. The leading bet commissioner, or stakeholder, in the public eye was Charles Mahoney, who held sway at the Hoffman House until 1910. ${ }^{64}$ Over most of this period, the standard betting and commission structure was for the betting commissioner to hold the stakes of both parties and charge a 5 percent commission on the winnings. If the commissioner trusted the credit-worthiness of the bettors, it was not necessary to actually place the stakes and instead the signed memorandum or letter of obligation sufficed. ${ }^{65}$

During the heyday of election betting in the late 1890s and early 1900s, the names and four-figure stakes of bettors filled the pages of New York's daily newspapers. By way of contrast, most of the reported wagering in the 1920s and 1930s involved sixfigure amounts advanced by unnamed leaders in the business or entertainment worlds. This shift to increasing anonymity reflected changes in tax laws, New York state antigambling legislation, and the public attitudes of the organized financial markets. The

\footnotetext{
${ }^{62}$ The Teller, (Lewiston, ID), 2 December 1876.

63 Downtown hotels, including the Fifth Avenue Hotel on $23^{\text {th }}$ and the Windsor on $46^{\text {th }}$ near where Jay Gould lived, were secondary locations for trading stocks and bonds in the mid-1890s. New York Curb Market, Committee of Publicity 1929, p. 9.

${ }^{64}$ New York Times, 26 March 1910, p. 16.

${ }^{65}$ New York Times, 10 November 1906, p. 1; 29 May 1924, p. 21; 4 November 1924, p. 2; Wall Street Journal, 29 September 1924, p. 13. New York Times, 9 November 1916, p. 3. For the long tradition of election betting, see New York Herald Tribune, 2 November 1940, p. 23.
} 
Hart-Agnew act was passed by the New York legislature in 1908 to outlaw professional bookmaking employing written bets (and was extended to cover oral bets in 1910). The prohibition was directed primarily against horse racing and the Tammany-linked Metropolitan Turf Association, but the law's passage also reduced betting on elections for several years.

Figure 3 graphs the cumulative number of article returned from online searches for "election bet" in the New York Times from 1851 to 1950 and the Washington Post from 1880 to 1950 . The Figure supports the conclusion that the heyday of election betting extended from the 1890s through the mid-1910s.

In 1912, the New York Curb Association publicly reminded its members that placing bets was contrary to New York laws. "Any member found betting, placing bets, or reporting alleged bets to the press will be charged with action detrimental to the interest of the association, which may lead to his suspension."66 The betting commissioners in the financial district initially responded by revising their contract form - creating a memorandum between "friends" to transfer money conditional on the election outcome - and by raising the commission rates to reflect their increased legal exposure. There was some talk of moving operations to New Jersey and many commissioners reduced or stopped keeping book. ${ }^{67}$ When the heat was reduced after a few years, election betting revived. Ironically, in the 1916 contest between President Wilson and Charles Hughes, who as New York Governor had signed the Hart-Agnew act into law, election betting on Wall Street reached its peak: \$10 million (or \$200 million in current dollars) was wagered on the national election.

By the late-1910s, the newspapers more commonly published stories centering on bet commissioners and bucket-shops in the financial district. (Bucketing was the practice of a broker accepting an order to buy a stock without actually executing it. The broker was essentially betting with the client about the changes in the stock's price.) In the early 1920s, three "brokerages" dominated election betting in the Wall Street financial district:

\footnotetext{
${ }^{66}$ Wall Street Journal, 8 June 1912, p. 5. In May 1924, both the New York Stock Exchange and the Curb Market passed resolutions barring their members from engaging election gambling. Again in late 1927, both exchanges blocked the use of "when issued" contracts to discourage gambling. Wall Street Journal, 23 December 1927, p. 11

${ }^{67}$ New York Tribune, 30 October 1908, p. 1. See also New York Times, 22 October 1909, p. 1; 11 July 1912, p. 10; 18 July 1912, p. 1. Regarding changes in commission rates, see the New York Tribune, 30 October 1908 p. 1
} 
W. L. Darnell \& Co., 44 Broad Street; J. S. Fried \& Co., 20 Broad Street; and G. B. de Chadenedes \& Co., also of 20 Broad Street. ${ }^{68}$ Other prominent New York bookmakers of the period include John Doyle, owner of a Broadway billiard academy, who principally handled wagers on sporting events such as prize fights and the World Series and Fred Schumm, a politically-connected café owner in Brooklyn, who dealt in both election and sports bets.

The organized financial markets continued to attempt to limit involvement of their members. For example, in May 1924 both the New York Stock Exchange and the Curb Market passed rules/resolutions against election gambling. The Exchanges liked to distinguish between their risk-sharing and risk-taking functions, which was socially productive, from gambling on sporting events such as horse races or prize fights, which were zero-sum entertainment activities whose outcomes did not affect the broader world. But unlike with sporting events, betting on elections potentially belonged in the riskinsurance category and the information it provided had real-world value. One could readily imagine a risk-averse owner of an investment project betting for a candidate unfavorable to the project to hedge against a "bad" election outcome. However, in practice it appears that bets were partisan in the sense that bettors took the side of their preferred candidate.

\section{Demise of the Election Betting Markets}

The formal political betting markets appear to have largely disappeared by 1944 , although informal bets continued to take place right up to the current period of internetbased markets. There are several explanations for the demise of the markets: (1) the rise of scientific polling; (2) the passing of several of the leading election betting commissioners; (3) the active suppression of the New York illegal gambling scene; (4) the contraction, during the early 1940s, of key sources of betting dollars; and (5) the legalization of horse race betting.

\footnotetext{
${ }^{68}$ Two of the three (Fried and Darnell) in fact were owned jointly by Samuel Solomon (aka Sam Boston) and the Silinsky brothers (Abraham, Frank, William). Although the newspapers often referred to the odds as quotations from the Curb, the links with the New York Curb Exchange were informal at best. Frank Silinsky did have a seat on the Exchange and Richard C. Fabb, an early publicist for the market, also worked for the Fried firm over the mid-1920s. "Bets to Exceed \$5,000,000" New York Times, 31 August 1924, p. 3.
} 
The press attention devoted to the Wall Street betting odds was due in part to the absence of creditable alternatives. In the early years of the $20^{\text {th }}$ century, the only other information available concerning future election outcomes came from the results from early-season barometer contests (such as the mid-September contest in Maine), overtly partisan canvasses, and unrepresentative straw polls. ${ }^{69}$ Over the $1894-1918$ period, the New York Herald published the results of its massive straw polls in the weeks leading up to election day. In November 1916, for example, it reported its tabulations of nearly onequarter million straw ballots collected from across the county. ${ }^{70}$ In the 1920 s and $1930 \mathrm{~s}$, Literary Digest, issued the best-known non-representative poll based on mass-mailing postcard ballots to millions of names listed in telephone directories and automobile registries. After predicting every presidential elections correctly from 1916 to 1932, the Digest famously called the 1936 contest for Alfred Landon, the Republican candidate, in the election that Franklin Roosevelt won by the largest Electoral College landslide ever.

The early polls based on scientific samples correctly predicted Roosevelt's victory. George Gallup, who had left academia and the advertising industry to form the American Institute of Public Opinion in 1935, was often credited with a singular gift of prophesy. ${ }^{71}$ However, the polls of the other pioneers of public opinion research including Elmo Roper, who began the Fortune Survey in 1935, and Archibald Crossley, also called the 1936 race correctly (as did the Wall Street betting odds). The numbers from scientific polls were available on a relatively frequent basis and were not subject to the moral objections against election betting. Newspapers, including the Washington Post, began to subscribe to the Gallup polling service and tout its weekly results in their pages. At the same time, they reduced their coverage of betting markets. Such trends are displayed in Table 1, which reports the number of articles in presidential election years in the New York Times and Washington Post returned in online search from selected "poll" and "election betting" terms from 1916 to 1944.

\footnotetext{
${ }^{69}$ Claude Everett Robinson, Straw Votes: A Study of Political Prediction (New York: Columbia University Press, 1932); Louis Bean, How to Predict Elections. (New York: Knopf, 1948); Susan Herbst, Numbered Voices: How Opinion Polling Shaped American Politics (Chicago: University of Chicago Press, 1993), pp. 69-88.

${ }^{70}$ New York Herald, 5 November 1916, p. 1.

71 "A Brief History of Polling," http://poll.orspub.com/static.php?type=about\&page=briefhistory presents a "potted" history of these events.
} 
Other factors also contributed to the demise of the Wall Street betting market. Several of the pre-eminent betting commissioners active in election wagering left the trade either due to death by natural causes (John Doyle) or to gang-land slayings (Sam Boston). ${ }^{72}$ La Guardia's general crack-down on illegal gambling, including "raids on brokers' offices" also made it "difficult to find betting commissioners in the financial district" by $1944 .^{73}$ Tammany Hall, which had often taken the Democratic side of wagers during the heyday of New York election betting, also fell onto hard times. La Guardia's repeated re-election as New York City mayor cut off much of Tammany's patronage, driving the organization to declare bankruptcy in 1943. High wartime taxes were purportedly crimping the pockets on Wall Street too. ${ }^{74}$ A final factor was the legalization of betting on horse races in New York in 1939. The possibility of betting several times each day at the track, rather than once or twice a year on elections, siphoned the dollars of bettors and bookmakers.

\section{Conclusion}

Election betting has a long history in Western countries. These markets often involved greater stakes and induced greater emotions than the internet markets of current times. The bets were such a central feature of culture in certain times that even those lacking the money to place a wager got involved. In the United States during the $18^{\text {th }}$ and $19^{\text {th }}$ centuries non-financial bets were wildly popular, where the losers had to roll peanuts with a toothpick down a street, climb up a greased pole, shave their hair or make other public gestures. In 1900, there were at least a half a million such "freak bets."75

\footnotetext{
${ }^{72}$ New York Times, 8 November 1940 p. 14, 4 August 1942 p. 1; New York World-Telegraph, 11 October 1944. Doyle retired and then died; Boston left the business after a close associate was killed as a result of a double-cross.

${ }^{73}$ New York World-Telegraph, 11 October 1944, which includes an analysis of why wagering in New York City on the 1944 Dewey-Roosevelt "was extremely quiet." For coverage of La Guardia's intensified wartime campaign against gambling and vice, see New York Times, 18 January 1943, p. 17; 21 June 1943, p. 1; 4 December 1943, p. 16; 18 December 1943, p. 17.

${ }^{74}$ Warren Moscow, The Last of the Big-Time Bosses: The Life and Times of Carmine De Sapio and the Rise and Fall of Tammany Hall (New York: Stein and Day, 1971), p. 24; New York Journal American, 18 August 1944; New York News, 1 November 1944.

${ }^{75}$ E. Leslie Gilliams, "Election Bets in America," Strand Magazine. (1901) XXI: 185-191.
} 
While it is sometimes claimed that political betting markets are a recent invention, they clearly are not. Rather it is the absence of such markets during the mid- and late- $20^{\text {th }}$ century which is the exception. 
Figure 1: A 1948 “Totalvoto" ticket for sale recently at EBay Italy.

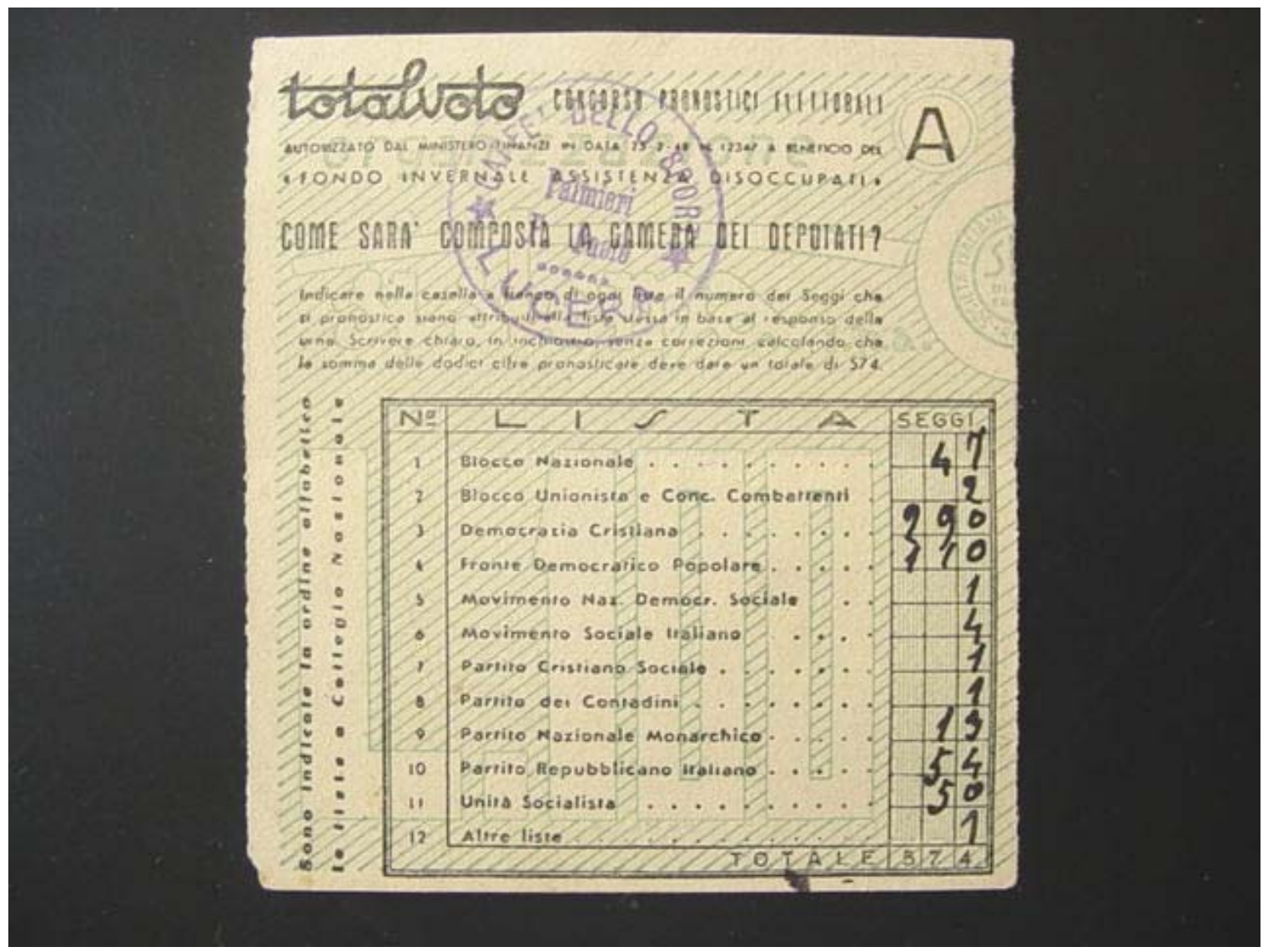


Figure 2: Cumulative Distribution of Articles on Election Betting, 1800-1860

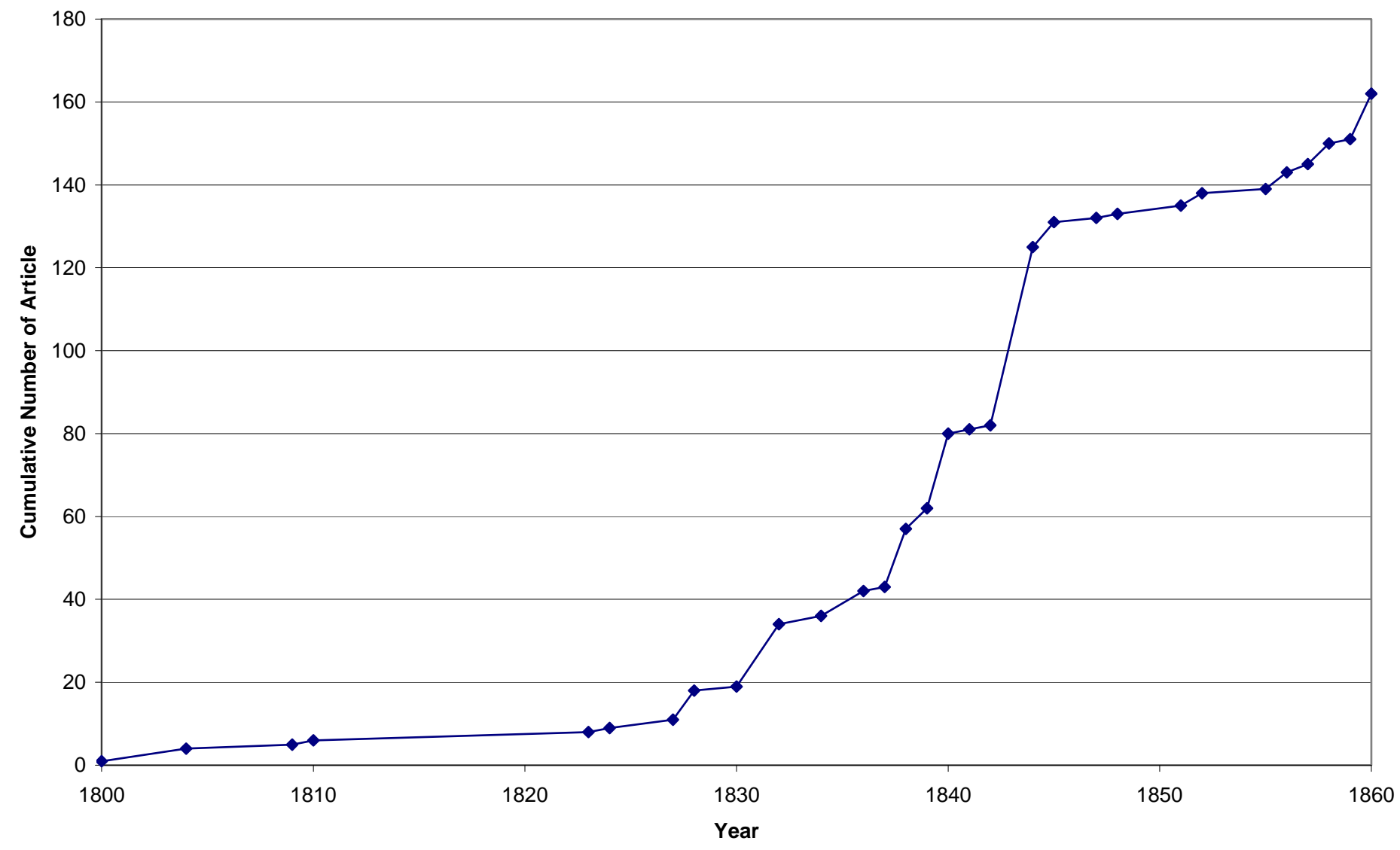


Figure 3: Cumulative "Election Bet" Articles in the NY Times and Washington Post, 1851-1950

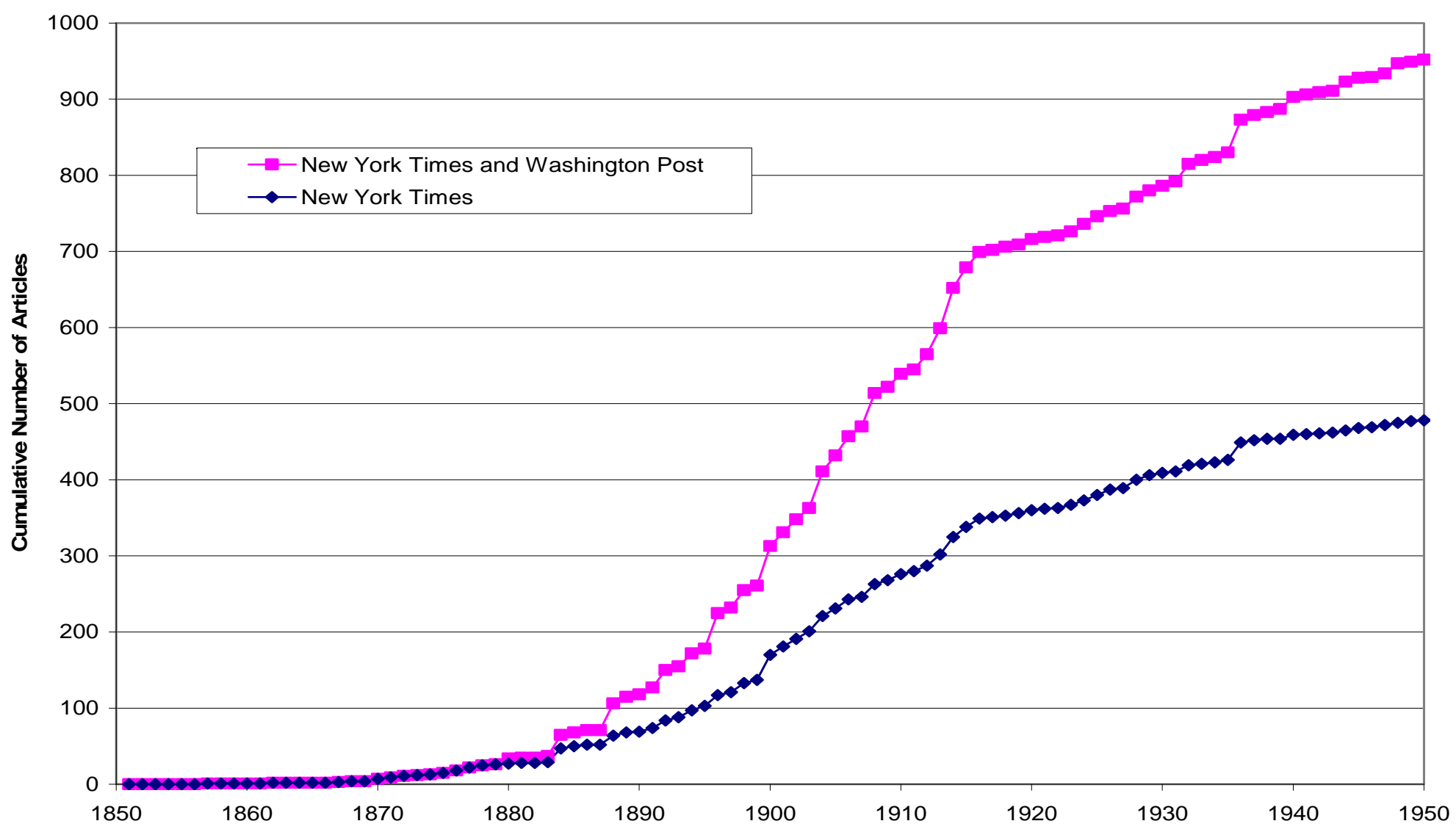


Table 1: Number of Articles Returned From Selected "Poll" and "Election Betting" Search Terms

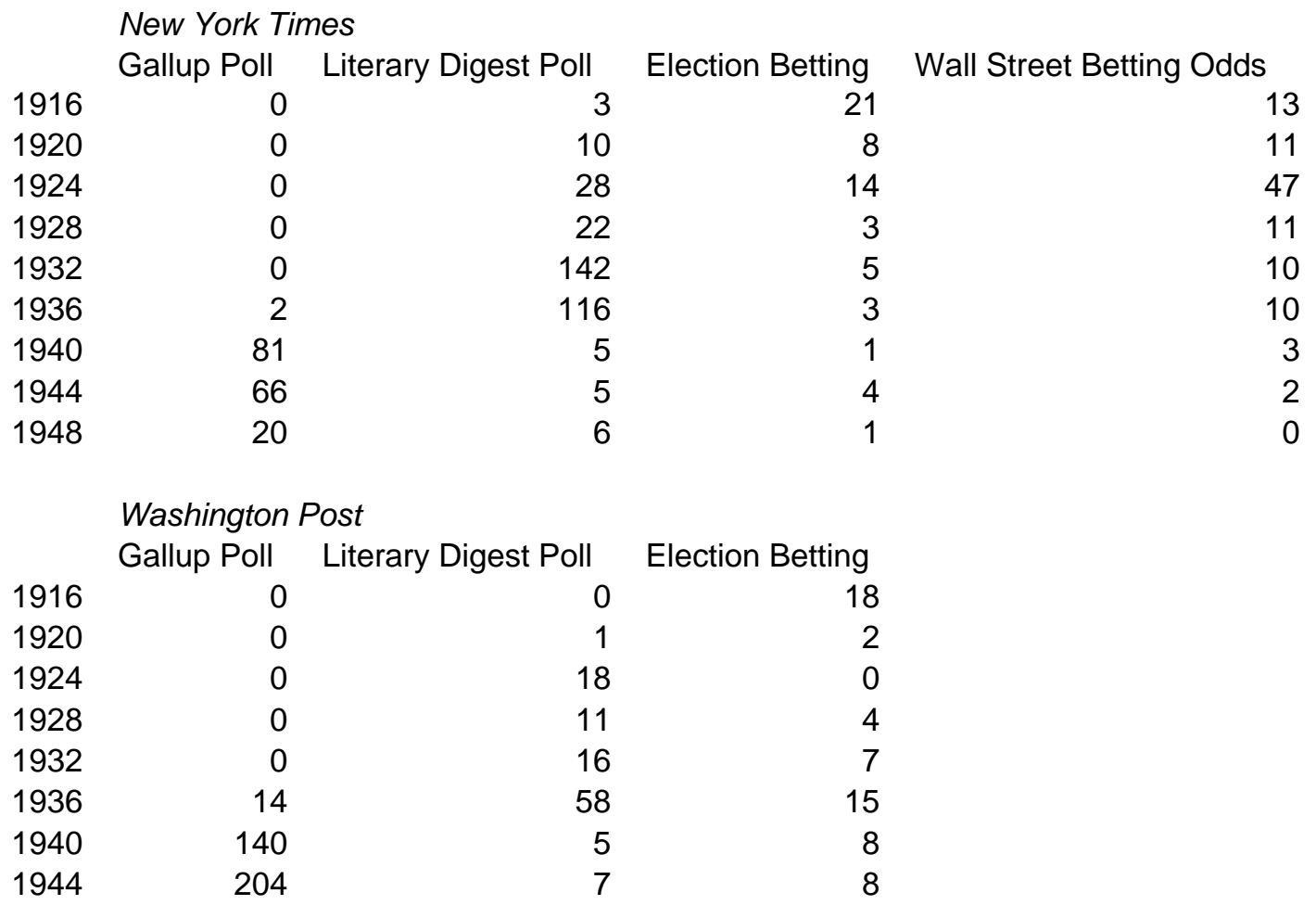

